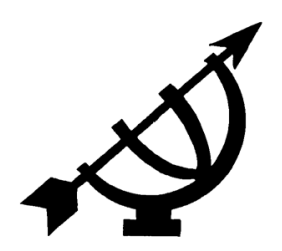

\title{
Leadership and power
}

\author{
V. Kessler \\ Research Fellow: Dept.of Philosophy \& Systematic Theology \\ University of South Africa \\ PRETORIA \\ and \\ Dean of Akademie für christliche Führungskräfte \\ Gummersbach \\ GERMANY \\ E-mail: volker.kessler@acf.de
}

\section{Abstract \\ Leadership and power}

Leadership does not exist without power. Thus we have to reflect on power in order to lay a theoretical foundation for responsible leadership. This interdisciplinary article collects insights from the disciplines of theology, sociology, and crosscultural management. It provides a concise summary of what a Christian leader should know about power in order to use his/her power in an adequate way. The theological reflection reminds us of the fact that, according to the Judeo-Christian tradition, God gave power to humankind (Guardini, 1998). Two opposite dangers are described in this article, namely the abuse of power on the one hand and the misconception of powerlessness as a Christian virtue on the other hand. The sociological section describes different forms of power. Following French and Raven (1960), it introduces seven power bases, which are illustrated by examples from society and the church. The next section describes the different cultural perceptions on power. It shows how the cultural parameter of power distance may influence the appropriate leadership style (Hofstede \& Hofstede, 2005). It is argued that our understanding of a right or wrong use of power is strongly influenced by the culture in which we grew up. The article concludes with a list of ethical guidelines on the use of power for responsible Christian leaders. 


\section{Opsomming}

\section{Leierskap en mag}

Leierskap sonder mag bestaan nie. Daarom moet ons op mag reflekteer om sodoende 'n teoretiese grondslag vir verantwoordelike leierskap te lê. Hierdie interdissiplinêre artikel weerspieël insigte vanuit die vakgebiede van teologie, sosiologie en multikulturele bestuur. Dit verskaf 'n bondige opsomming van dit wat 'n Christenleier behoort te weet oor mag om daardeur sy/haar mag toepaslik te kan gebruik. Die teologiese refleksie herinner aan die feit dat, volgens die Judeo-Christelike tradisie, God mag aan die mensdom gegee het (Guardini, 1998). Twee teenstrydige gevare word in hierdie artikel bespreek, naamlik die misbruik van mag aan die een kant, en aan die ander kant die wanpersepsie van magteloosheid as 'n Christelike deug. Die sosiologiese gedeelte beskryf verskillende vorms van mag. Deur Franch en Raven (1960) na te volg, word sewe magsbasisse voorgestel wat met voorbeelde uit die gemeenskap en die kerk toegelig word. Die daaropvolgende gedeelte beskryf die verskillende kulturele persepsies van mag. Dit toon hoe die kulturele parameter van magsafstand die toepaslike leierskapstyl kan beïnvloed (Hofstede \& Hofstede, 2005). Dit word gekonstateer dat 'n mens se begrip van die korrekte of verkeerde gebruik van mag sterk beïnvloed word deur die kultuur waarin ons grootgeword het. Die artikel eindig met 'n lys etiese riglyne oor die gebruik van mag deur verantwoordelike Christenleiers.

\section{Introduction}

My hypothesis is that leadership does not exist without power as understood in a broad sense (see below). Thus, we have to reflect on power in order to lay a theoretical foundation of responsible leadership. This article attempts to discuss different facets of the phenomenon of power. The aim is to give a concise summary of what a Christian leader should know about power in order to use his/her power in an appropriate way.

The approach of this article is interdisciplinary. Researchers from different academic disciplines have investigated the phenomenon of power. Often, these discussions are focused within one discipline: theologians quote other theologians and sociologists quote other sociologists. However, in both disciplines the intercultural aspects are often neglected. By combining insights from different disciplines, this article wants to contribute to a more holistic understanding of the phenomenon of power. This will enable us to derive ethical 
guidelines for responsible leadership from these insights, which is also the aim of this article. Since different academic disciplines contribute to the understanding of the phenomenon of power, we will consult these disciplines in order to obtain a theoretical basis for responsible leadership. Key aspects of the investigation of responsible leadership include: What is power? (Philosophical reflections, section 2); What does the Judeo-Christian worldview teach about the origin and the use of power? (Theology, section 3); How can power be exercised? (Sociology, section 4); and How is power perceived in different cultures? (Cross-cultural management theory, section 5).

\subsection{Personal motivation}

One cannot lead without power. This insight was not always evident to the author. Born in 1962, my German school education was influenced by the so-called "'68-movement" which was very antiauthority. I was, therefore, strongly sceptical about hierarchy and formal power. In a somewhat naïve understanding of servantleadership (Greenleaf, 1977), I used to give talks titled "Leading without power". It took me some time to understand the following three facts about power:

- Power is more than formal power

- Power is not bad in itself

- One cannot lead without power

Being a theologian I will especially consult the Judeo-Christian tradition. As a practical theologian I am eager to learn from the social sciences and cultural anthropology. As a protestant theologian I regard the Bible as the highest authority concerning ethical questions.

\section{Defining leadership and power}

There is a great deal of debate about the correct definition of leadership. Neuberger (2002:12-15) lists 39 different definitions from the German literature alone - and even this list is not complete. In this article I use the word leader in a very broad, pragmatic sense inspired by Greenleaf $(1977: 15 ; 1998: 31): 1$ A leader is a person whom other persons follow; i.e. a person who dares to say "I will go,

1 Cf. Greenleaf's statement: "The only test of leadership is that somebody follows - voluntarily" (Greenleaf, 1998:31). I omit the criterion "voluntarily", because I regard formal power as a legitimate form of power in certain contexts. 
come with me" and where people follow this call. A leader in this sense might be a boss in a typical workplace hierarchy, a leader within an organisation of volunteers, a teacher at a university, a speaker or an author who has influenced people through his/her ideas, et cetera.

By using the term Christian leadership I refer to two different groups. Firstly, I refer to leaders in a specific Christian context like a church congregation or a Christian non-governmental organisation (NGO). Secondly, I refer to leaders who work in a secular environment like the business world or the government, but who want to lead their staff/followers according to their Christian worldviews and ethical standards, whether or not these followers share the Christian worldview of the leaders.

Of course, the literature on power is marked by a deep disagreement over the basic definition of power (cf. Luhmann, 1969; Habermas, 2006; Lukes, 1986; or Zaaiman, 2007 for detailed discussion of various definitions). Instead of offering a new definition I will refer to four classical definitions, because these are widely accepted and they cover the most essential aspects. My starting point is three classical monographs on power. These famous monographs were written in the context of the two World Wars, perhaps because during times of war the human experience of power and powerlessness is very intense. Firstly, consider the German sociologist Max Weber (1864-1920) and his volume Economy and society, published posthumously in 1921, which is still "widely considered the most important single work in sociology" (Camic et al., 2005:back page). Weber's definition of power has often been quoted:

By power is meant every opportunity/possibility existing within a social relationship, which permits one to carry out one's own will, even against resistance, and regardless of the basis on which the opportunity rests. (Weber, 1980:28; translation VK. $)^{2}$

In 1938, in anticipation of the next World War, the British mathematician and philosopher Bertrand Russell (1872-1970), wrote a book on power in which, among other things, he analysed the power

2 "Macht bedeutet jede Chance, innerhalb einer sozialen Beziehung den eigenen Willen auch gegen Widerstreben durchzusetzen, gleichviel worauf diese Chance beruht." (Weber, 1980:28.) 
play of the Nazi regime. According to him "power may be defined as the production of intended effects" (Russell, 2004:23).

After the Second World War, people all over the world, and especially the German people, were very wary of the abuse of power after their experiences during the War, especially with the destructive power of the atom bomb. In 1951, the Italian-German philosopher Romano Guardini (1885-1968) had the following special message for those people who were reluctant to use power at all:

In itself, power is neither good nor evil; its quality is determined by him who wields it. ... Thus power is as much a possibility for good and the positive as it is a threat of destruction and evil. The danger grows with the growth of power, a fact that is brought home to us today with brutal clarity. (Guardini, 1998:124.)

Guardini (1998:121) gives a short and concise definition of power: "Power is the ability to move reality."

These three academics agree on the fact that power is the potential, the ability, to do something. It is irrelevant whether the instrument of the power is actually used. In most cases it suffices that people believe that a powerful person could do this or that. Incidentally, each of these authors had a different worldview: Max Weber was protestant, Bertrand Russell was an avowed atheist (cf. Russell, 1957), and Romano Guardini was a Catholic priest.

Another famous definition of power was given by the American political scientist Robert Dahl: "A has power over B to the extent that he can get B to do something that B would not otherwise do." (Dahl, 1957:202.) Dahl explicitly uses an expression, which is also implicit in Weber's definition, namely power over. Russell and Guardini define power more broadly as a capacity to achieve intended effects, namely power to. Dowding (1996:4) suggests to use the terms outcome power for "power to" and social power for "power over". This article deals with both aspects.

\section{Theological reflections on power}

\subsection{The origin of human power according to the Judeo- Christian tradition}

Despite many examples of tremendous abuses of power in human history, the Judeo-Christian tradition espouses the simple fact that human beings have power, because God - creator of heaven and 
earth - gave it to them. The creation story links the creation of humankind directly to the command to rule, to power over the other creatures:

Then God said: 'Let us make human beings in our image, after our likeness, to have dominion over the fish in the sea, the birds of the air, the cattle, all wild animals on land, and everything that creeps on the earth.' (Gen. 1:26. $)^{3}$

This is high praise of humankind - human beings are made in the image of God. Unfortunately, there is a huge speculative overload on the concept of God's image (imago Dei). In contrast to its heavy anthropological and theological impact in Christian theology and beyond, the term God's image only appears at three places in the Hebrew Old Testament: Genesis 1:26, 27; 5:3; 9:6.4 The Hebrew word used here is zelem, originally meaning statue (Wildenberger, 1995:557). In the Old Orient, the statue of a king represented the king himself and his power. It demonstrated his dominion in a particular geographical area (Wolff, 1981:160). The isolated position of Genesis 1:26 has left much room for theological speculation. During the twentieth century, Old Testament science began to free itself from dogmatic overload and speculation (Schroer-Staubli, 2005:2).

Today, the consensus within the Old Testament theology (SchroerStaubli, 2005:2) ${ }^{5}$ seems to be that being God's image means being God's representative, God's deputy. By being God's representative human beings have power! Benno Jacob, a Jewish theologian who had great influence on Old Testament theologians like Von Rad, wrote in 1934: "In the dominion over the earth and the animals, man is the earthly representative of God." (Jacob, 2000:59; translated VK. $)^{6}$ In 1973, Wolff wrote in his well-known Anthropology of the Old Testament:

3 Bible quotations are taken from the Revised English Bible (1990).

4 There are two further occurrences in the late Greek writings, i.e. Wisdom 2:23 and Sirach 17:3.

5 In Systematic Theology Luther's and Calvin's interpretation of imago Dei are often still followed.

6 "In der Herrschaft über die Erde und die Tierwelt ist der Mensch der irdische Stellvertreter Gottes." (Jacob, 2000:59.) 
It is precisely in his function as ruler that he is God's image. ... Accordingly man is set in the midst of creation as God's statue. $\mathrm{He}$ is evidence that God is the Lord of creation; but as God's steward he also exerts his rule, fulfilling his task not in arbitrary despotism but as a responsible agent. His rule and his duty to rule are not autonomous; they are copies. (Wolff, 1981:160161.)

Psalm 8:5-8 celebrates the high and powerful position the human beings were granted by God:

Yet you have made him little less than a god, crowning his head with glory and honour.

You make him master over all that you have made, putting everything in subjection under his feet:

all sheep and oxen, all the wild beasts ...

The lordship includes the ability to exercise power:

Man's natural God-likeness consists in this capacity for power, in his ability to use it and in his resultant lordship. ... Man cannot be human and as a kind of addition to his humanity, exercise or fail to exercise power; the exercise of power is essential to his humanity. (Guardini, 1998:133.)

As Genesis 1:27 clearly shows, the imago Dei refers both to man and woman. Both are created in God's image, both are God's earthly representatives, both were given the command to rule, to exercise power over the earth and its creatures.

Genesis 9:6 and Psalm 8:5-8 indicate that God's image was not lost after the fall7 (as opposed to what was taught by Augustine, Luther and Calvin who more or less identified God's image with the status of original righteousness, and this identification led to the dogma that the imago Dei was lost after the fall in Genesis 3). Today, every human being still bears God's image as was meant in Genesis 1:26:8 as being God's representative - notwithstanding the fact that

7 Cf. Von Rad's statement in Kittel's dictionary: "Davon, daß die Gottesebenbildlichkeit für den Menschen nunmehr verloren ist, weiß das Alte Testament nichts." (Von Rad, 1935:390.)

8 This meaning of God's image has to be distinguished from the concept of Christ's image unfolded by the apostle Paul in the New Testament and applied to Christians only (cf. Scheffzyk, 1969; and Kessler, 2004:197-238 for a detailed discussion of these two different meanings of God's image). 
this dominion was often misunderstood and led to the exploitation of God's creation.

\subsection{Lordship as service: power and responsibility}

If we remember that human power has its roots in the imago Dei this should encourage the use of power with good conscience. But this relation also includes a sense of human responsibility. According to the understanding of leadership in the Old Orient, a leader was responsible for his subordinates. In the Bible power is always connected with accountability or responsibility. A leader is accountable to those who have entrusted him/her with power and for those who find themselves in his/her sphere of influence. Guardini (1998:134) summarises this:

Only when these facts have been accepted, does the phenomenon of power receive its full weight, its greatness, as well as its earnestness, which is grounded in responsibility. If human power and the lordship which stem from it are rooted in man's likeness to God, then power is not man's in his own right, autonomously, but only as a loan, a fief. Man is lord by grace of God, and he must exercise his dominion responsibly, for he is answerable for it to Him who is Lord by essence. Thus sovereignty becomes obedience, service.

As God's representative, a human being has lordship and power. As God's representative she/he should always exercise this power with responsibility towards God.

The passages quoted above from Genesis 1 and Psalm 8 deal with power over non-human creatures. They do not refer to power over other people, which is the case in the context of leadership in the way we defined it. Indeed, the Old Testament sets certain limits on the use of power. Human beings shall not have dominion over other human beings as they have over animals, because the other human beings are also created in God's image (Gen. 9:6). As will be discussed later in the context of cultural power distance, the Old Testament also limited the power of kings and other authorities. The kings of Israel never had absolute power like the kings of the surrounding countries, and they were upbraided by the prophets if they ignored these limitations (Strydom \& Wessels, 2000).

Ultimately, according to the Christian worldview, all human power, including the power over other human beings, is derived from God's power; see Romans 13:1b: “ ... for all authority comes from God, and the existing authorities are instituted by Him". Thus, God will 
hold those given power accountable for the way they exercise their power.

\subsection{Authority versus power?}

Sometimes Christians would argue: "We are interested in authority, not in power." The word authority sounds more positive and more spiritual, whereas the word power tends to have negative connotations. However, building up a contrast between authority and power is not as spiritual as it might seem at first glance. Luke 4:36b reports that Jesus had authority and power: "What is there in this man's words? He gives orders to the unclean spirits with authority (exousia) and power (dynamis), and they go." The Greek word dynamis means the ability to do something. It can be translated with force, strength or power. The Greek word exousia refers more closely to the permission, the legitimation to do something. A bank robber with his gun has the power to get money but not the legitimation. In other situations people may have the legitimation to do something but lack the power to enforce this right. Jesus had authority and power - and passed on both to his disciples: "He gave them power (dynamis) and authority (exousia) to overcome all demons and to cure diseases." (Luke 9:1.) Authority and power should go hand in hand.

\subsection{The ethics of power}

When is it legitimate to use power? A short answer is: the exercise of power is legitimate if and only if it is carried out in order to create something good or to prevent something bad (cf. Kiechle, 2005:911). Of course, in a specific situation it is often difficult to decide whether a certain act will really lead to good or prevent bad. This formula at least shows a direction.

There are two big dangers of exercising power wrongly: the first danger is the abuse of power, while the second one is the exact opposite: no use of power at all (power vacuum). Some Christians wrongly interpret powerlessness as a Christian virtue (Kretzschmar, 2002:52).

The Bible has much to say about abuse of power. Many passages of the Old Testament prophets like Micah 2-3 and Ezekiel 22:27; 34:25 accuse the reigning parties of abusing their power (cf. Strydom \& Wessels, 2000). The New Testament mentions many power addicted persons like King Herod or the Pharisees. It also gives the name of a power addicted church leader, Diothrepes, "who enjoys 
taking the lead"9 (3 John 9), and who tries to expel other Christians from the congregation in order to gag his opposition. Diothrepes has become a prototype of power addicted people in the Church (Kessler \& Kessler, 2004:16-22). Sadly enough, church history is full of examples of power abuse. The psychological reasons for abusing power are manifold: it may be greed for money and/or power, or for prestige; or it may be as a result of insecurity in a leadership position - especially if the leader has just recently been promoted; or it may be that the leader simply lacks leadership abilities. See Kretzschmar (2002:53-58) for suggestions on how to develop authentic Christian leaders through moral and spiritual formation.

However, the Bible does not condemn the wish to take the lead in the church (cf. Matt. 20:26; 1 Tim. 3:1). The desire for power becomes a problem if power is treated as an end in itself (cf. Russell, 2004:216). Power is a legitimate means. But power shall never be an end in itself. Those who aim at power as an end in itself, and who aim at power just for the sake of power, miss the right target - which corresponds to the original meaning of the Greek word hamartia (sin). The Jesuit priest Kiechle, rightly remarks that whoever looks for power as an end in itself, does not regard it as a gift from God, but starts to idolise power, binds him-/herself to power and abuses it (Kiechle, 2005:10). Aiming at power for power's sake leads to power addiction.

Some people are so concerned about the abuse of power that they do not dare to exercise power at all. The difficulty is that if a leader does not exercise his/her power, there will be a power vacuum and power addicted people will try to fill this power vacuum. Actually, it is essential that leaders with the right character take responsibility and exercise their power wisely, adequately, but nevertheless use their power, if they love their people.

If you love your neighbour, you will wish for power to make him happy. To condemn all love of power, therefore is to condemn love of your neighbour. (Russell, 2004:216.)

Greenleaf coined the term servant-leadership for the business world in 1970, and describes the consequences if gifted persons with the right attitude refuse to lead:

9 The Greek word philoproteuon only occurs once in the New Testament. 
Who is the enemy? Who is holding back more rapid movement to the better society that is reasonable and possible with available resources? ... Not evil people. Not stupid people. Not apathetic people. Not the 'system'. ... In short, the enemy is strong natural servants who have the potential to lead but do not lead, or who choose to follow a non-servant. They suffer. Society suffers. And so it may be in the future. (Greenleaf, 1977:45-46.)

The conclusion is obvious. It is a misunderstanding to regard powerlessness as a Christian virtue. Leaders need to use power in order to lead towards a better society.

\section{Power as a sociological process}

The fundamental theological reflections in section 3.1 were on power in a broad sense (power to), regardless of whether other people are involved or not. Since this article is on leadership, which always involves other people, we will now focus on social power, i.e. power involving other people. Thus we need a definition that covers both aspects: power over other people and power to. Zaaiman's proposed definition is suitable for our context: "Power is the ability ... to influence the actions and the opinions of people and so causes effects in affairs and people" (Zaaiman, 2007:374).

\subsection{The essence of power relations}

According to Russell $(2004: 4,6)$ power is a core term in sociology:

In the course of this book I shall be concerned to prove that the fundamental concept in social science is Power, in the same sense in which Energy is the fundamental concept in physics. Like energy, power has many forms ...

The laws of social dynamics are - so shall I contend - only capable of being stated in terms of power in its various forms.

Max Weber's definition of power already indicates that power presupposes a social relationship. Power is a social process between human beings or groups of human beings (Hentze et al., 1997:389). In order to exercise power there have to be two actors, either two persons or two parties: the powerful actor, indicated by $P$, and a subordinate actor, indicated by $S$, and there must be a social relationship between both. For example, a teacher living in South Africa and a student of an elementary school in Germany usually would not have any social relationship. The South African teacher thus cannot exercise any power over the German student. 
Figure 1: Power relationship between the powerful $P$ and the subordinate $\mathbf{S}$

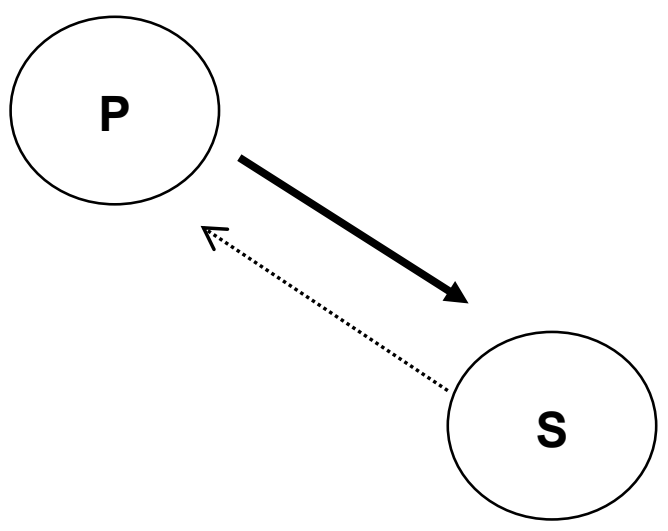

Power relations are asymmetric: the bold line in Figure 1 shows that $\mathrm{P}$ has power over S.10 The subordinate $S$ has, at least, some power, indicated by the dotted line. Sometimes S's power is merely the power to withdraw from P's area of influence either by terminating the work contract, seceding from church, fleeing or in extreme situations by committing suicide, as the Zealots did in Masada 73 AD during the Jewish-Roman war. They preferred to die as free persons. The conclusion that can be drawn from this extreme example is that $P$ has power over $S$ only if $S$ allows it. There is no leadership if nobody follows. Even in the case of brute force $S$ has a choice, namely to follow $P$ or to give up his/her own life. Subordination means that $S$ allows $P$ to exercise power over him/her.

It needs to be emphasised that the subordinate $S$ also has power. Many people feel powerless although they are not without power. They try to abdicate responsibility by complaining, "I cannot change it". They keep on complaining about their boss and/or their church elders for years and years. These people do not notice that they have a choice. They could, for example, terminate the work contract. They may have good reasons for not doing so, for example because they have an obligation to feed their family. But then it is their decision not to leave. They choose to stay.

10 Two persons may share two different power relationships with each other. Assume that a wife works part-time in her husband's company. At work he is $P$ and she is $\mathrm{S}$. At home it might be the other way round. 


\subsection{The different bases of social power}

Social power can be exercised in many different ways. Russell (2004:24) listed three: "A. By direct physical power over his body ...; $B$. By rewards or punishments as inducements; C. By influence on opinion".

In 1959, French and Raven published an essay listing five different bases of power. By basis of power they meant the relationship between $P$ and $S$, which is the source of the power (French \& Raven, 1960:262).

These five bases of P's power are:

(a) reward power, based on S's perception that $\mathrm{P}$ has the ability to mediate rewards for him;

(b) coercive power, based on S's perception that $\mathrm{P}$ has the ability to mediate punishments for him;

(c) legitimate power, based on the perception by $S$ that $P$ has a legitimate right to prescribe behavior for him;

(d) referent power, based on S's identification with P;

(e) expert power, based on the perception that $\mathrm{P}$ has some special knowledge or expertness.

(French \& Raven, 1960:263; nomenclature adapted VK. ${ }^{11}$ )

These definitions indicate that it is irrelevant whether $\mathrm{P}$ really is able to mediate rewards/punishments or whether $P$ has a legitimate right or expert knowledge. It is only relevant whether $S$ assumes this, rightly or wrongly.

Many authors built on this essay by French and Raven and introduced further bases of power.12 In Table 1, I follow French and

11 I adapted this quotation to my nomenclature, i.e. I replaced their $O$ with $P$ and their $P$ with $S$.

12 Raven himself added a sixth base of power: informational power, which is rooted in P's ability to provide information to $S$ not previously available to him (Raven, 1965:372; Raven \& Kruglanski, 1970:72). Yukl and Falbe (1991) added the two bases "Control over information" and "Persuasiveness". In 1992 Finkelstein introduced the concept of prestige power, and in 2004 Nye (quoted in Pietersen, 2009:200-203) introduced the concept of soft power, which refers to shared values. 
Raven $(1959 ; 1965)$ but I split up the referent power into two different power bases (no. 6 and 7).13 These seven power bases are classified into four groups, and ordered along a continuum between "positional power" and "personal power". Positional power is connected to the position a person holds whereas personal power depends on the traits or qualities of a person. The power base no. 1 refers to a pure positional power, and the power bases no. 6 and 7 are pure personal power, whereas the power bases no. 2-5 are a mixture of the two.

Table 1: Taxonomy of seven power bases

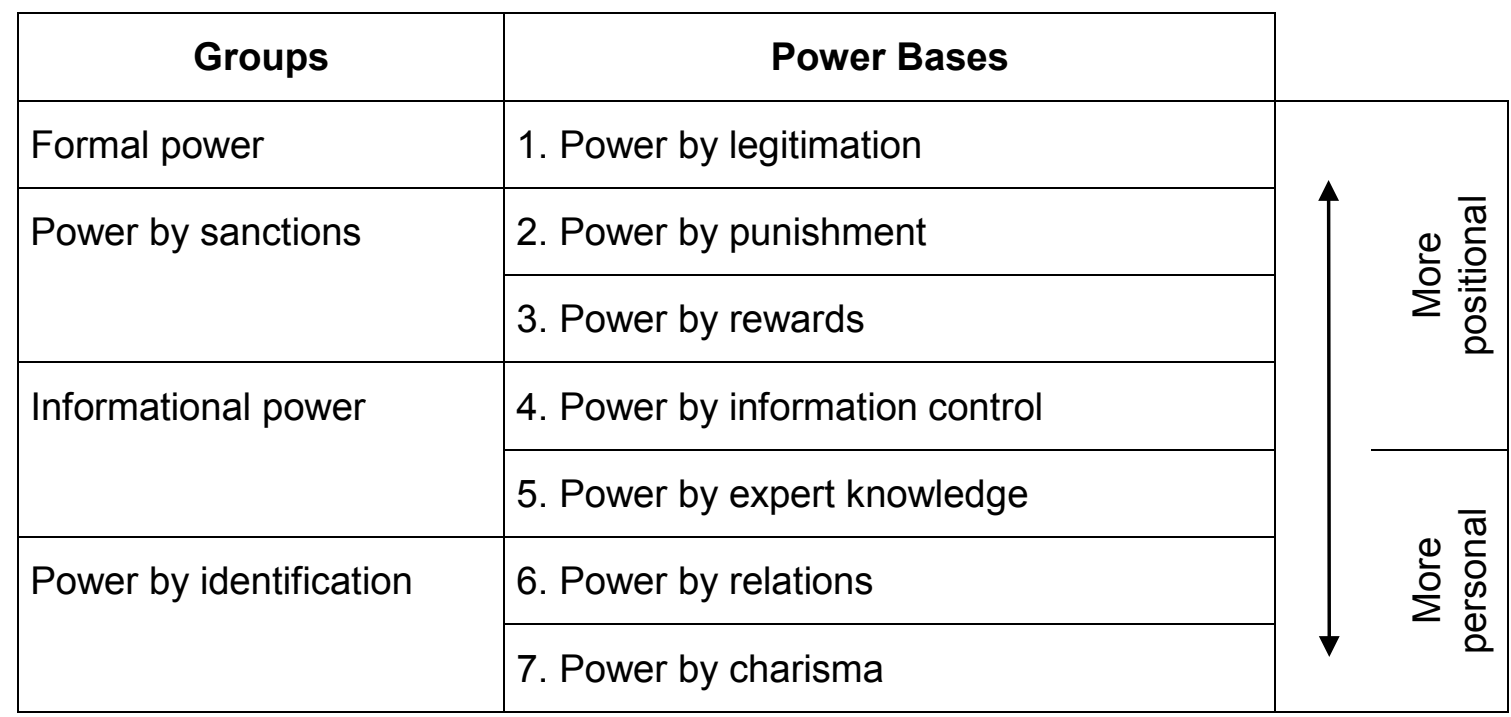

A policeman, for example, exercises power by legitimation. So might a boss within an organisational hierarchy. It represents a pure form of positional power. There are certain rules/norms identifying the power of an office holder. If a leader in an organisation refers too often to his/her formal power he/she is probably lacking personal authority. But in some contexts, especially in conflict situations, it may be helpful and necessary to refer to one's formal authority. Paul, for example, referred to his formal authority as an apostle in the conflict situations in Corinth (1 Cor. 1:1; 9:1; 2 Cor. 1:1; 11:5) and in Galatia (Gal. 1:1).

In the case of power by sanctions, we have to distinguish between whether a person can mediate punishments and/or rewards. In

13 Other taxonomies of power bases have been published, e.g. Popitz (2004:2532); Hentze et al. (1997:380-381), and Pietersen (2009:201). 
working relations the boss usually has both options. He/she can increase the salary of a subordinate or terminate the contract; he/she can send the subordinate to a bigger, more beautiful office or to a smaller, noisier office. This is also known as the "stick and carrot" method.

In some instances there is, however, only one form of sanction applicable. Many charity organisations rely on voluntary helpers who are not paid for their work. Usually there is no way of punishing voluntary helpers, but they can be rewarded - for example with a silver medal for 25 years of voluntary work. On the other hand, traffic police regulating the traffic usually wield power through punishments only, not through rewards.

At first glance "power by rewards" looks more benign and more positive than "power by punishment". Most of us would prefer to praise somebody rather than punishing him/her. However, in some contexts "power through punishment" actually makes more sense. In a scenario "power through reward" $P$ becomes active each time when $S$ behaves as $P$ wishes. In a scenario "power through punishment" $P$ needs only to become active when $S$ does not behave according to P's will. This is the case with traffic regulation. If somebody drives too fast or parks wrongly she/he will be punished. Whereas nobody will be rewarded by the police for driving at the right speed or parking correctly. Power through reward would increase the working load of the police tremendously. Thus, in this context it is much more effective to use "power by punishment".

The strongest punishment the church has is expulsion from the congregation, which the church members - depending on the church doctrine they espouse - may perceive as leading to eternal damnation. In his analysis of the priestly power of the Catholic Church, Russell (2004:41-54) points out that the medieval popes held a powerful sanction. With reference to Matthew 16:19 they claimed to have the "keys of the kingdom of heaven". Obviously, there were many people before Martin Luther dissatisfied with the behaviour of the popes, but the keys of the kingdom of heaven provided an effective way of crushing opposition, because people feared losing the permission to enter into heaven. The situation changed with Luther's theology of justification:

Since the power of the Church had been based upon the power of the keys, it was natural that opposition should be associated with a new doctrine of justification. Luther's theology made it 
possible for lay princes to despoil the Church without fear of damnation ... (Russell, 2004:51).

An interesting interpretation on the power play during the Reformation by an atheistic philosopher.

Informational power can be exercised in two different ways: either through control of information or through expert power. "Power by information control" is usually largely connected to the position somebody holds, such as the power of a CEO who has access to special sources of information, whereas "expert power" is related more to the person who has become an expert in a certain field and who will retain this expertise even if he leaves the position. The immense power of the mass media today relies on "power by information control". The mass media decide what news will, or will not, be available to the public and what will be not.

As mentioned above, expert power is more of a personal power than a positional power. It is, however, not a pure personal power. People believe in their medical doctors not only because of their expertise, but also because of their position. The power base "expert power" is a good example for the fact that the subordinate $S$ voluntarily decides whom he allows exercising power over him. If $S$ is no longer convinced about P's expertise, he/she will probably look for another expert. It is also clear that expert power is always restricted to a certain arena. I trust in the expertise of the car mechanic in respect of my car, but I will not give him any expert power in respect of planning my future.

Power by identification takes place when $S$ identifies with $P$. $S$ follows $P$ not because he/she is forced to, but because $S$ believes in $P$ as a person. This trust may have grown during a long-standing relationship. This is what is meant by "power by relation". It is based on loyalty and friendship. There are also so-called "charismatic leaders" in terms of Weber's definition of charismatic leadership (Weber, 1980:124, 140-144). People follow charismatic leaders because they are attracted by their charisma and/or by their message even if they have not known them for long. The former South African president, Nelson Mandela, is obviously an example of a charismatic leader. The former German chancellor, Helmut Kohl, was not a gifted speaker and he was not perceived as a charismatic leader at all. But Kohl was very good in building loyal relations with other politicians like George Bush (USA) and Mikhail Gorbachev (USSR). These trust relations enabled Kohl to enforce the German reunification in 1990/1991. 
Often Christian leaders want to become charismatic leaders. However, if a leader without any charisma (in Weber's definition of the word) tries to exercise "power through charisma" she/he will never succeed. If a non-charismatic leader wants to exercise power through identification he has to focus on building strong relations and thus increase his power base of "relational power".

These seven power bases are basic forms. In reality, power is often exercised through a combination of several power bases. For example, Pope John Paul II had legitimate power over the Catholic people just because he was the Pope. This formal power base was strengthened through his personal charisma, and through his charisma he also influenced people outside of the Roman Catholic Church. Thus, a leader may use several power bases simultaneously.

The effectiveness of power bases may change while culture changes. For example, in the early 1960s Germans had a great deal of respect for formal power. This has changed since then. For some decades there has been a steady shift from monolithic, hierarchically structured organisations to networks of small, flexible organisations. Today, big companies tend to outsource more and more services to new small companies. They still work together on a long-standing basis, but the smaller company is no longer subordinate to the big company, at least not in a formal way. The relationship has to be negotiated through mutually agreed upon contracts. Thus networks of trust are increasingly replacing hierarchies of command. Trust is becoming the crucial issue (Covey et al., 2006). As a consequence, personal authority (power through expertise, relationships, charisma) becomes more important than positional, formal authority.

This sociological shift from positional power to personal power explains some conflicts arising in many of today's western Christian churches. Today's church leaders (55+) grew up with a high respect for positional authority. When they were young they would never have dared to question their church leaders. Today the youth do not have these inhibitions. They put critical questions to church leaders because they believe that authority does not rely on position, but on personal competence. The older generation perceives this behaviour to be disrespectful of an office installed by God. On the other hand, the younger generation feels alienated because church leaders do not always respond to critical questions, and these feelings might lead them to suspect that power is being abused. 
These examples of the different power bases should demonstrate that there is legitimate place for each power base. Each power base can be misused, but none of the seven power bases is unethical per se. As a Christian leader I have to reflect: Which power base can I use in a specific situation? Which kind of power fits both the context and my personality?

\section{Power in intercultural perspective}

The previous example illustrating the generational problem within the church shows that our understanding of a right/wrong use of power is strongly influenced by the culture in which we grew up. The differences become even stronger when we look at the perception of power in totally different cultures.

In 1980, Geert Hofstede from the Netherlands published the first systematic study on intercultural management (Hofstede \& Hofstede, 2005:ix). He interviewed IBM employees in 50 countries and three regions. This IBM study generated four dimensions to measure cultural differences, namely power distance, individualism versus collectivism, masculinity versus femininity, and uncertainty avoidance (Hofstede \& Hofstede, 2005:23).

Hofstede and Hofstede (2005:46) defined power distance as "the extent to which the less powerful members of institutions and organizations within a country expect and accept that power is distributed unequally". Note that power distance is measured from the perspective of less powerful, ordinary people, whereas most modern leadership literature is written from the perspective of powerful people. Leadership can only exist together with followers. Thus leaders cannot be successful if they ignore the cultural parameter of power distance. A large power distance means that the less powerful people of this kind of culture accept and partly even expect power to be distributed unequally and that the powerful people will demonstrate their insignia of power. Behaviour like this would not be accepted in a culture with a low power distance.

In 1991 the USA management professor Robert J. House, initiated another research project on intercultural management, known as the GLOBE research project. It involved far more people than Hofstede's IBM study two decades before (House et al., 2004). During 1994-1997, 170 researchers interviewed 17300 managers from 951 organisations in 62 cultures (House et al., 2004:xv, xxii). They used nine dimensions of cultural variation and changed some of Hofstede's dimensions. However, they stuck to his definition of power 
distance (Hofstede \& Hofstede, 2005:517), and their study confirmed that power distance is an important parameter for describing a culture.

\section{Table 2: Differences between large and small power distance (Hofstede \& Hofstede, 2005:57, 59, 67; cf. also House et al., 2004:536.)}

\begin{tabular}{|c|c|}
\hline Large power distance & Small power distance \\
\hline \multicolumn{2}{|c|}{ Key differences in general } \\
\hline $\begin{array}{l}\text { Might prevails over right: whoever holds } \\
\text { the power is right and good. }\end{array}$ & $\begin{array}{l}\text { The use of power should be legitimate and } \\
\text { follow criteria of good and evil. }\end{array}$ \\
\hline $\begin{array}{l}\text { Inequalities among people are expected } \\
\text { and desired. }\end{array}$ & $\begin{array}{l}\text { Inequalities among people should be } \\
\text { minimised. }\end{array}$ \\
\hline Mostly small middle class. & Mostly a large middle class. \\
\hline The powerful should have privileges. & All should have equal rights. \\
\hline $\begin{array}{l}\text { Privileges and status symbols are normal } \\
\text { and popular. }\end{array}$ & $\begin{array}{l}\text { Privileges and status symbols are frowned } \\
\text { upon. }\end{array}$ \\
\hline \multicolumn{2}{|c|}{ At school } \\
\hline Teachers should take all initiative. & $\begin{array}{l}\text { Teachers expect initiative from students in } \\
\text { class. }\end{array}$ \\
\hline Teachers are gurus. & Teachers are experts. \\
\hline $\begin{array}{l}\text { Students accord teachers respect, even } \\
\text { outside of class. }\end{array}$ & Student treat teachers as equals. \\
\hline \multicolumn{2}{|c|}{ In organisations } \\
\hline $\begin{array}{l}\text { Hierarchy in organisations reflects } \\
\text { existential inequality between higher and } \\
\text { lower levels. }\end{array}$ & $\begin{array}{l}\text { Hierarchy in organisations means an } \\
\text { inequality of roles, established for } \\
\text { convenience. }\end{array}$ \\
\hline Centralisation is popular. & Decentralisation is popular. \\
\hline \multicolumn{2}{|c|}{ At the workplace } \\
\hline $\begin{array}{l}\text { There is a wide salary range between the } \\
\text { top and the bottom of the organisation. }\end{array}$ & $\begin{array}{l}\text { There is a narrow salary range between } \\
\text { the top and the bottom of the organisation. }\end{array}$ \\
\hline Subordinates expect to be told what to do. & Subordinates expect to be consulted. \\
\hline $\begin{array}{l}\text { The ideal boss is a benevolent autocrat, or } \\
\text { "good father". }\end{array}$ & The ideal boss is a resourceful democrat. \\
\hline
\end{tabular}


(Hofstede \& Hofstede, 2005:57, 59, 67; cf. also House et al., 2004: 536.)

According to Hofstede and Hofstede (2005:82-85), there is a strong correlation between collectivism and power distance. Almost all collectivist countries such as Asia, Latin America and black Africa, score high on power distance. Most of the individualistic countries score low on power distance. They are from the Anglo-Saxon world (UK, USA, Canada, Australia, white population in South Africa), Scandinavia, and the Germanic countries (Germany, Switzerland, Austria, the Netherlands). Latin Europe is indeed different. They combine high individualism with mid-range power distance. Top managers in France may blatantly declare: "I have power", whereas German top managers may describe their position as "having opportunities to do something".

The GLOBE study (House et al., 2004:518) identified four main phenomena influencing the power distance index of a culture. It argued that "a society's predominant belief system and its religion or philosophy will have the most profound and enduring influence on power distance" (House et al., 2004:526), and exemplified as follows:

In the GLOBE dataset, Nordic Europe, Germanic Europe, and Anglo clusters score low on societal power distance practices, but have comparatively stronger scores on participative leadership. These three clusters share protestant reformation as a major influence. The reformed clusters profess the direct relationship of God and humans without the mediation of the church or the clerics, and thus nurtured a vision of humans as responsible persons. (House et al., 2004:554.)

This statement is further supported by looking at the beginning of the Reformation. That an unknown monk like Martin Luther would dare to stand up and to speak against the powerful Pope sets an example for small power distance. Although the word protestantism was coined after the special protest at the Reichstag zu Speyer in 1529 , it also describes something inherent in the Protestant movement where people often protested against the authorities, which finally led to the fragmentation of the Protestant movement.

Our conclusion is that our understanding of power, authority and submission, and our judgement of whether a particular use of power is good or bad is first and foremost shaped by the culture in which we grew up. 
We should be aware of this dependency. Often authors who claim to be describing "the biblical leadership" end up describing what they consider to be good leadership from their cultural perspective. There is always the danger of focusing on those Bible verses that support one's own view on leadership culture and ignoring other Bible verses.

One might ask whether there is an ideal power distance index in line with Christian ethics. On the one hand, the Bible teaches us to respect authorities. On the other hand, it clearly condemns might prevailing over right (Lev. 19:15; Micah 3:9; etc.). Since the Bible's focus is on the ethics of power and not very much on the organisational structuring of power, 14 we cannot derive a specific ideal number for a "Christian" power distance index. A serving leader simply has to take into account the power distance of the people or staff whom he/she is serving. In a country where people maintain a large power distance, they expect directive leading and might be confused by a western-oriented participative leadership style. The staff might even draw the conclusion that the leader is incompetent, because he/she does not tell them what to do. On the other hand, if a leader comes from a high power distance culture to a country with a low power distance without changing his/her leadership style, the staff might easily allege an abuse of power.

How do we know whether we exercise our power adequately? The first problem is our blind spot. We do not see our own deficiencies as leaders. It can easily happen that we preach and teach about servant leadership in the full conviction that this is exactly the way we lead - whereas our immediate environment might judge our actual exercise of power very differently. The second problem is that subordinates often do not dare to speak openly. In cultures with a high power distance an open criticism of a leader might even be regarded as inappropriate behaviour. The Dutch leadership expert Kets de Vries (2004:71) suggests that each leader needs a "licensed fool" in his/her environment, a person who dares to tell the truth, who holds up a mirror, even if it hurts. The danger of relying on one's own self-image is already demonstrated by the Old Testament

14 Some biblical advice on organisational structuring of power is found in the separation between kingly and priestly power in the Old Testament. The Israel king was not allowed to perform priestly sacrifices whereas in the surrounding countries the king was often the high priest or even a god himself. Separation of power is a method of preventing the abuse of power. 
proverb "A fool's conduct is right in his own eyes; to listen to advice shows wisdom" (Prov. 12:15).

\section{Conclusion}

This article has introduced us to various facets of power in the context of Christian leadership. I trust that it has become clear why it is worthwhile to listen to the views emerging from within different disciplines and to bring together various insights on power. Especially in the context of leadership, it is important to overcome a mono-cultural view, because in most cases leaders influence people from different cultures.

By way of a conclusion ethical guidelines for Christian leaders that arise from the previous sections are provided below.

\section{Ethical guidelines for exercising power as a Christian leader}

- $\quad$ Say Yes to power. Power is a gift from God.

- $\quad$ Remember that every power is on loan from God - and we are accountable to Him.

- $\quad$ Exercise your leadership as a responsible service: serving God, serving the organisation, and serving the people outside and inside of the organisation.

- Use your power for good or to prevent bad. But never strive for power as an end in itself.

- $\quad$ Which power base are you willing and able to use (depending on your context and your personality)? Each power base may be used appropriately or abused.

- $\quad$ Respect the culture of the people you lead and especially their perception of power. Where does biblical ethics demand a transformation of the culture (e.g. if might prevails over right)?

- Be open to criticism of your use of power. Ask mature persons for feedback on your leadership style.

\section{List of references}

CAMIC, C., GORSKI, P.S. \& TRUBEK, D.M. 2005. Max Weber's "Economy and society": a critical companion. Stanford: Stanford University Press.

COVEY, S.M.R., MERRILL, R.R. \& COVEY, S.R. 2006. The speed of trust: the one thing that changes everything. New York: Free Press.

DAHL, R. 1957. The concept of power. Behavioral science, 2:201-215. 
DOWDING, K. 1996. Power. Buckingham: Open University Press.

FRENCH, J.R.P. \& RAVEN, B. 1960. The bases of social power. (In Cartwright, D. \& Zander, A., eds. Group dynamics. 3rd ed. New York: Harper \& Row. p. 259-269.)

GREENLEAF, R. 1977. Servant leadership: a journey into the nature of legitimate power and greatness. New York: Paulist Press.

GREENLEAF, R. 1998. The power of servant leadership: essays by R.K. Greenleaf. Ed. by L.C. Spears. San Francisco: Berret-Kohler.

GUARDINI, R. 1998. The end of the modern world. Wilmington: ISI Books.

HABERMAS, J. 2006. Hannah Arendts Begriff der Macht (1976). (In Habermas, J., Red. Politik, Kunst, Religion. Stuttgart: Reclam. S. 103-126.)

HENTZE, J., KAMMEL, A. \& LINDERT, K. 1997. Personalführungslehre. 3. Aufl. Bern: Haupt.

HOFSTEDE, G. \& HOFSTEDE, G.J. 2005. Cultures and organizations: software of the mind. 2nd ed. New York: McGraw-Hill.

HOUSE, R., HANGES, P.J., JAVIDAN, M., DORFMAN, P.W. \& GUPTA, V. 2004. Culture, leadership, and organisations: the GLOBE study of 62 societies. Thousand Oaks: Sage.

JACOB, B. 2000. Das erste Buch der Tora: Genesis. Stuttgart: Calwer.

KESSLER, M. \& KESSLER, V. 2004. Die Machtfalle: Machtmenschen in der Gemeinde. 3. erw. Aufl. Gießen: Brunnen.

KESSLER, V. 2004. Ein Dialog zwischen Managementlehre und alttestamentlicher Theologie: McGregors Theorien X und $Y$ zur Führung im Lichte alttestamentlicher Anthropologie. Pretoria: University of South Africa. (D.Th. thesis.)

KETS DE VRIES, M.F.R. 2004. Chefs auf die Couch. Harvard business manager Deutschland, 2004:62-73, Apr.

KIECHLE, S. 2005. Macht ausüben: Ignatianische Impulse. Würzburg: Echter.

KRETZSCHMAR, L. 2002. Authentic Christian leadership and spiritual formation in Africa. Journal of theology of Southern Africa, 113:41-60.

LUHMANN, N. 1969. Klassische Theorie der Macht. Zeitschrift für Politik, 16(2):149-170.

LUKES, S., ed. 1986. Power. Oxford: Blackwell.

NEUBERGER, O. 2002. Führen und führen lassen. 6. Aufl. Stuttgart: Lucius \& Lucius.

PIETERSEN, E. 2009. Leadership, power and influence. (In Van Zyl, E., ed. Leadership in the African context. Cape Town: Juta. p. 195-221.)

POPITZ, H. 2004. Phänomene der Macht. Tübingen: Mohr Siebeck.

RAVEN, B.H. 1965. Social influence and power. (In Steiner, I.D. \& Fishbein, M., eds. Current studies in social psychology. New York: Holt. p. 371-382.)

RAVEN, B.H. \& KRUGLANSKI, A.W. 1970. Conflict and power. (In Swingle, P.G., ed. The structure of conflict. New York: Academic Press. p. 69-109.)

RUSSELL, B. 1957. Why I am not a Christian. London: Allen \& Unwin.

RUSSELL, B. 2004. Power. London: Routledge Classics.

SCHEFFZYK, L., Hrs. 1969. Der Mensch als Bild Gottes. Darmstadt: Wissenschaftliche Buchgesellschaft.

SCHROER, S. \& STAUBLI, T. 2005. Die Körpersymbolik der Bibel. Gütersloh: Gütersloher Verlagshaus.

STRYDOM, J.G. \& WESSELS, W. 2000. Prophetic perspectives on power and social justice. Pretoria: Biblia Publishers. 
VON RAD, G. 1935. Die Gottesebenbildlichkeit im AT. (In Kittel, G., Hrsg. Theologisches Wörterbuch zum Neuen Testament. 2. Band. Stuttgart: Kohlhammer. S. 387-390.)

WEBER, M. 1980. Wirtschaft und Gesellschaft. 5. Ed. Tübingen: Mohr Siebeck. WILDENBERGER, H. 1995. säläm Abbild. (In Jenni, E. \& Westermann, C., Hrsg. Theologisches Handwörterbuch zum Alten Testament. Band 2. 5. Aufl. Gütersloh: Christliche Kaiser, Gütersloher Verlagshaus. S. 556-563.) WOLFF, H.W. 1981. Anthropology of the Old Testament. 2. ed. London: SCM.

YUKL, G. \& FALBE, C.M. 1991. Importance of different power sources in downward and lateral relations. Journal of applied psychology, 76:416423.

ZAAIMAN, J. 2007. Power: towards a third generation definition. Koers, 72(3):357-375.

\section{Key concepts:}

intercultural leadership

leadership ethics

power, abuse of

power bases

Kernbegrippe:

interkulturele leiding

leierskapetiek

magsbasisse

magsmisbruik 